\title{
Human and Technology in the Animation Industry
}

\author{
Ferric Limano* \\ Animation Program, Visual Communication Design Department, School of Design \\ Bina Nusantara University \\ Jakarta 11480, Indonesia \\ ferric.limano@binus.ac.id \\ *Correspondence: ferric.limano@binus.ac.id
}

\begin{abstract}
Humanism is a term in intellectual history that is often used in the fields of philosophy, education and literature. In classical greek times, this humanism manifested itself in paideia, a classical greek education system that was intended to translate the vision of the ideal human being. However, this classical Greek perspective departs from a purely natural view of humans. So, humans and education are like two sides of a coin that cannot be divorced. Technology is also the result of educated human beings, technology holds many beautiful promises, but in the experience and history of technology also contains threats and dangers contained in it. In this study, how to discuss the history and development of the Indonesian animation industry, from a human and technological perspective. This study used qualitative research methods, by taking secondary data regarding the history of animation development then analyzed descriptively with a comparison of the role humans and technology. The result of this research is to provide a viewpoint of thinking in the animation industry that humans and technology can coordinate together, resulting in many animation actors who maximize potential in animation technology.
\end{abstract}

Keywords: Animation; Industry; Human; Technology

\section{INTRODUCTION}

The definition and development of education, Humanism is a kind of inevitable premise of humanity itself, natural necessity that never dies, the basic articulation of self-esteem awareness. Humanists themselves are often labeled as secular, subversive, arrogant or individualist - a label that is very memorized by religious and moralists. Humanism is an articulation of basic and key humanity that keeps culture, religion, politics and science and technology civilized. Without it, it is easy for all systems to become violent and cruel. Truth, tradition, dignity, nation, power, even morals or God will be sacrificed.

Humanism is a term in intellectual history that is often used in the fields of philosophy, education and literature. In classical greek times, this humanism manifested itself in paideia, a classical greek education system that was intended to translate the vision of the ideal human being. However, this classical Greek perspective departs from a purely natural view of humans.

In medieval times, in Classical Greece, the ideal human view was one who experienced the harmony of body and soul, a condition in which humans attained eudaimonia (happiness). Therefore, in the classical Greek traditional curriculum, known as artes liberals or liberal arts, there are seven subject areas taught in order to achieve arête (virtue, virtue). The seven subject areas are grammar, speaking ability (rhetoric), logic, arithmetic (mathematics), geometry (geometry), astronomy and music. Which is divided into 2 divisions; Trivium (lower division) is grammar, speaking ability (rhetoric) and logic. Meanwhile, those included in the Quadrivium category (upper division) are arithmetic (mathematics), geometry (geometry), astronomy, and music. (Samho, 2008).

So paideia or "the art of educating" in classical Greece is often seen as a milestone in the early history of civilization through education or human intellectual awareness. This educational art continued to develop in the 
medieval period by Augustine and Thomas Aquinas. This paideia was not sufficient only in terms of exact sciences but also needed non-exacts.

The education model in classical and medieval greek, despite having different visions and orientations, is a serious attempt to affirm the existence of life. So, humans and education are like two sides of a coin that cannot be divorced, but united so that they are functional. Intellectual, emotional, social and spiritual reasoning that makes human beings whole and fully as a person are sharpened in and through education. The peak of self-identity maturity as a human being is experiencing the harmony of soul and body in the confession of faith that he is God's creation.

Definition and technological developments. In this part of technology, the writer draws a lot of understanding from Yuval Harari's book in "21 Lessons for the 21st Century". In Yuval's view of the book Sapiens, examining the human past, examining how an insignificant ape became the ruler of planet Earth (Harari, 2014). Whereas in his second book, Yuval explores the future of long-term life, contemplating how humans eventually became gods, and what might be the ultimate destiny of intelligence and consciousness. (Harari, 2017).

Technology holds a lot of beautiful promises, but in the experience and history of technology also contains threats and dangers that are contained in it. Since the companies and entrepreneurs leading the technological revolution in the 21 st century are naturally inclined to sing praises for their creations, it is the task of philosophers and historians to sound the alarm and fully explain what could go terribly wrong.

In the human experience in this century, with the flow of globalization that cannot be limited, especially the widespread internet communication media, making social media a forum for discourse in it. For example, Facebook using AI (Artificial Intelligence) to create a global community that will protect human freedom and equality? Don't you think the answer is to reverse the process of globalization and re-empower the nation-state? or perhaps it is necessary to go back further, and draw hope and wisdom from the sources of ancient religious traditions?

People have debated the meaning of life for thousands of years. We cannot continue this debate without the limits of a looming ecological crisis, the growing threat of weapons of mass destruction and the emergence of new disruptive technologies will not allow it. Perhaps most importantly artificial intelligence and biotechnology are giving humans the power to reshape and rebuild life. Soon one has to decide how to use this power - based on some implicit or explicit story about the meaning of life.

Even in this century it is difficult to deal with the ongoing revolutions in information technology and biotechnology. Today computers have made financial systems so complex that only a few humans can understand them. As AI continues to evolve, we may soon achieve what it will do to the political process? Can you imagine a government humbly waiting for an algorithm to approve its budget or new tax reforms? meanwhile, central serverless block chain networks and cryptocurrencies such as bitcoin completely transform the monetary system, so radical tax reform is inevitable (Harari, 2018).

We don't know what the job market will be like in 2050. It is generally agreed that machine learning robotics will transform nearly every line of work from producing yogurt to teaching yoga. So are we on the brink of a terrifying upheaval, or is such a prediction another example of Luddite's unfounded hysteria? hard to say. The fear that automation will create massive unemployment takes us back to the 19th century, and so far they have never materialized since the start of the industrial revolution, for every job replaced by machines, at least one new job was created and the average standard of living has increased. dramatically. But there is good reason to think that this time is different, and that learning machines will be a real game changer.

Humans have two types of abilities - physical and cognitive in the past, machines competed with humans primarily in gross physical abilities, while humans maintained a great advantage over machines in terms of cognition. Therefore, when manual work in agriculture and industry is automated, new jobs emerge in the service sector that require the kind of cognitive skills that only humans possess: learning to analyze, communicate, and especially understanding human emotions. However, AI is now beginning to outperform humans in many of these skills, including understanding human emotions. And we don't know of something like a third area of activity beyond the physical and cognitive - where humans will always maintain a safe edge.

The loss of many traditional jobs in everything from art to healthcare will be partially offset by the creation of new jobs for humans. Doctors who focus on diagnosing known diseases and administering familiar treatments may be replaced by AI doctors. But precisely because of that, there will be more money paying human doctors and laboratory assistants to do innovative research and develop new medicines or surgical procedures. AI might help 
create new jobs for humans in other ways. Instead of humans competing with AI they can focus on AI services and improvements. This in every sector will experience significant changes that cause the job market in 2050 to be characterized by cooperation between humans and AI.

There are also some issues in the technology challenge including those who own their data are the people who own the future. Humans have bodies, technology will probably manipulate our entire bodies in the same way today they manipulate our eyes, fingers and credit cards. We may miss the good days when online is separated from offline (Harari, 2018).

Objective research is humans role and technology in the animation industry from historical study. The purpose of this study is to provide a viewpoint in the animation industry that understanding about the roles, challenges, and opportunities of humans and technology can coordinate together, resulting in many animation actors who maximize their potential in animation technology.

\section{METHODS}

The method used in a research is qualitative. The data used is secondary data obtained from online media or offline literature. The data taken is a historical study of the world history animation, which is marked by the discovery of new technologies in animation. Then from these data a comparison will be made between humans and technology in animation development. The results of the comparison will be analyzed descriptively. So that give understanding the roles, challenges, and opportunities of humans and technology in the development animation.

\section{RESULT AND DISCUSSION}

When we look at the study from the literature above, it can be understood that the basis of paideia education is the notion of humanism itself. In today's civilization, humans experience a new challenge in life, especially problems that arise when technology is increasingly sophisticated, and the times are changing work patterns in all industrial sectors. It is even possible that the work that was previously done by humans, is now done by machines, either software or hardware.

The limitation of the problem in this study is, an example of a work case in the animation field. Where there is a huge change from the classic art of animation, to animation today. In the following, the author will discuss some examples of cases of animation development.

The development of world animation is divided into five chapter according to technology and methods of working on animation at that time (Cavalier, 2011). The first chapter started before 1900, which is called (The origin of Animation). In this stage, sequential pictures were found and told stories in cave walls in prehistoric times, then continued to develop until the 1800 s when tools were found that could make moving images. These discoveries include Traumatrope (1825) by an English physicist, John Airton Paris, Phenakitiscope (1831) by Josept Plateau from Belgium, Daedalum (1834) by William Horner from England which was later developed by William F Lincoln to become Zoetrope in 1860, until the discovery of the praxinoscope at the end of the 19th century by Charles Emile Reyanud in France in 1877. In this phase, humans are not familiar with digital technology in animation, still looking for the right tool to create moving images (Kurnianto, 2015). 
Table 1 First Chapter - The Origin of Animation

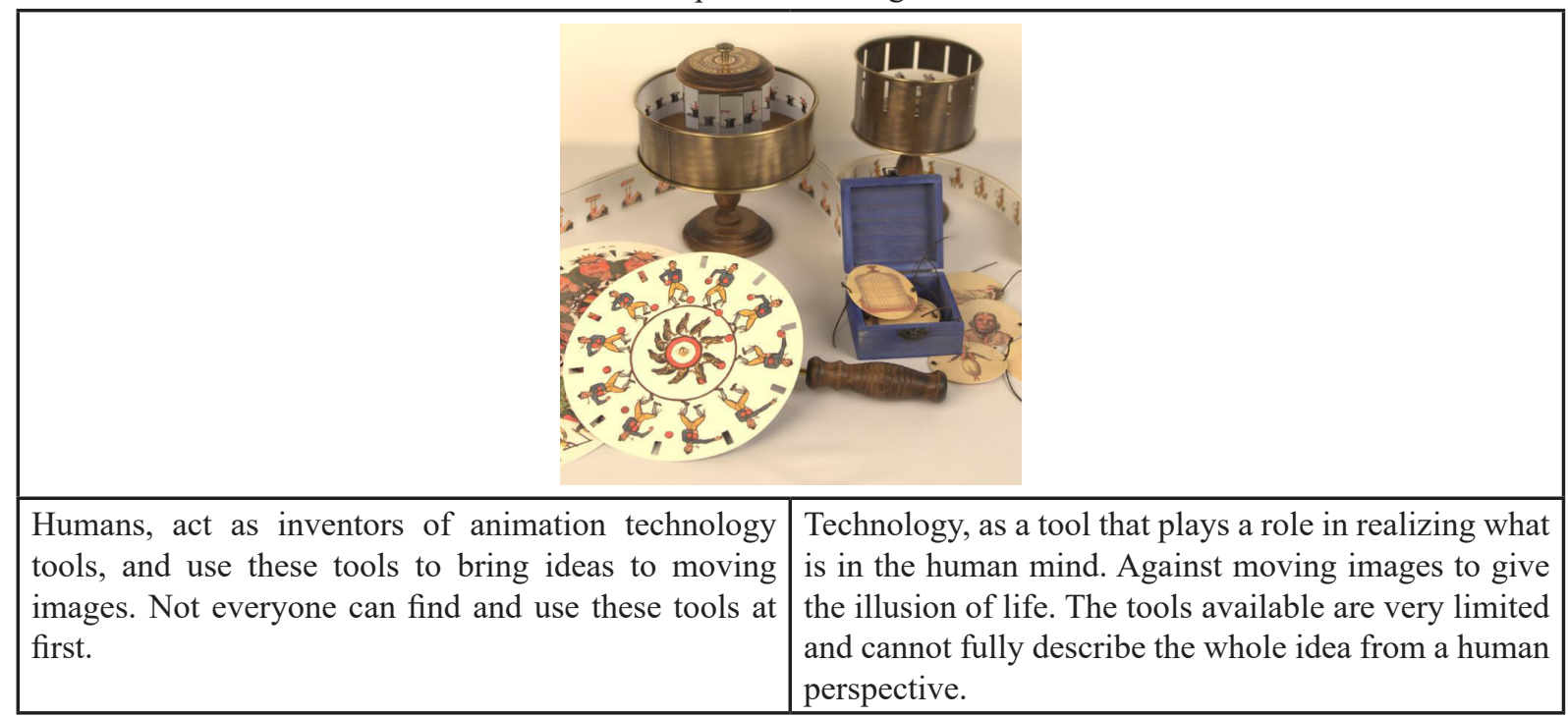

The second chapter of Film Animation: The Era of Experimentation (1900-1927). In this era in 1895 Lumire Brothers introduced the cinmatographe device in France. Where was the beginning of the development of animation experimentation of motion and techniques in early cinematography animated films. Starting there is making animated films using stop animation techniques, done by transferring moving images through photos. During this period, many animators began to experiment with animation, such as Walt Disney, Emili Cohl, and Edison. Humans in this case have a very important role technically in working on animation production, and require good skills in image consistency. Meanwhile, technology as a medium for capturing images from each animator at that time and combining them into a film.

Table 2 Second Chapter - The Era of Experimentation

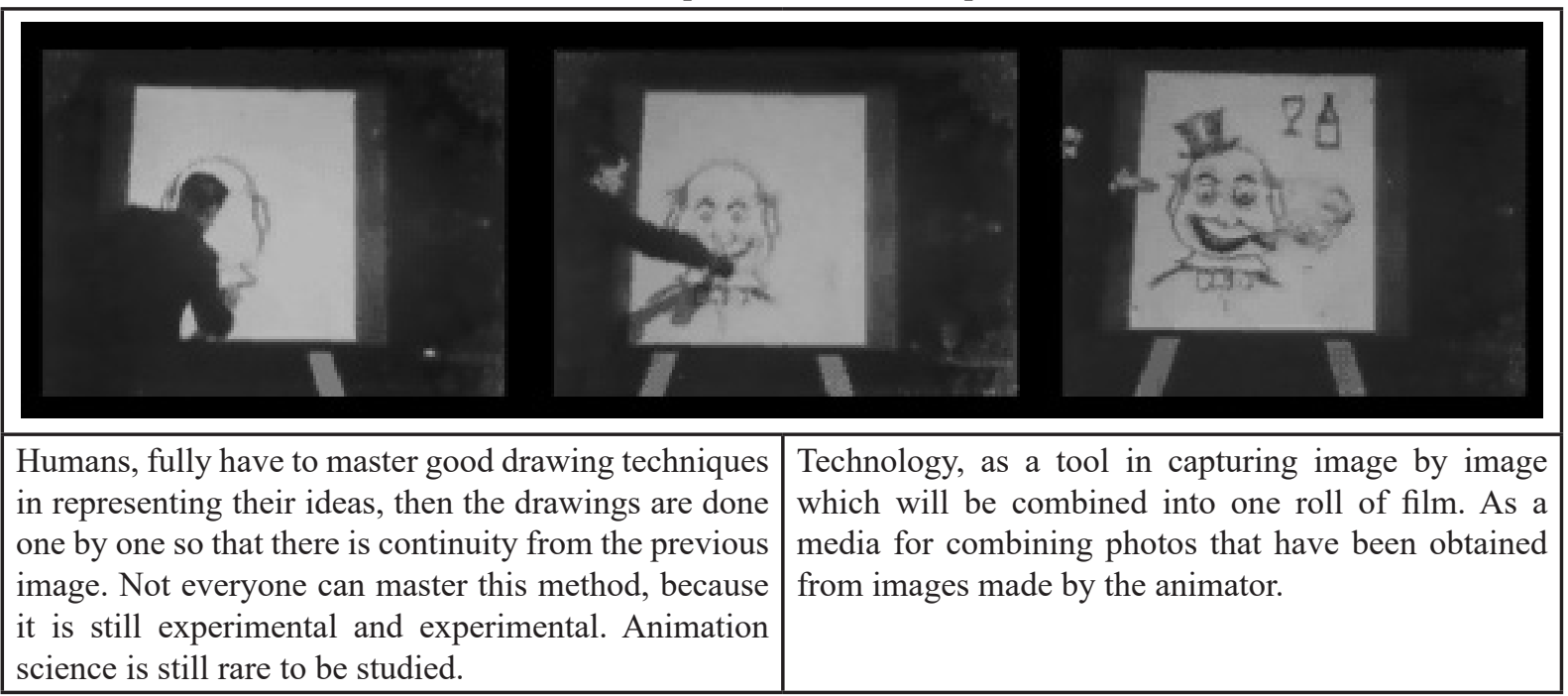

The Golden Age of Cartoon, Third chapter 1028-1957. This era is the golden age for animation as a whole, both artistic and technical. This era was also dominated by Walt Disney's era, because at that time it was started by the success of Steamboat Willie, Mickey Mouse. And the emergence of a stunning animated feature film by Walt Disney, namely Snow White and the Seven Dwarfs in 1937, also appeared several companies such as the Warner brothers, Hannah Barbara. During this period, people began to be equipped with special skills in making animated films, especially when large companies emerged that provided direct learning facilities for their employees. Thus without realizing it has provided an area of non-formal education for the community at that time. The technology side still fully relies on hardware machines. 
Table 3 Third chapter - The Golden Age of Cartoon

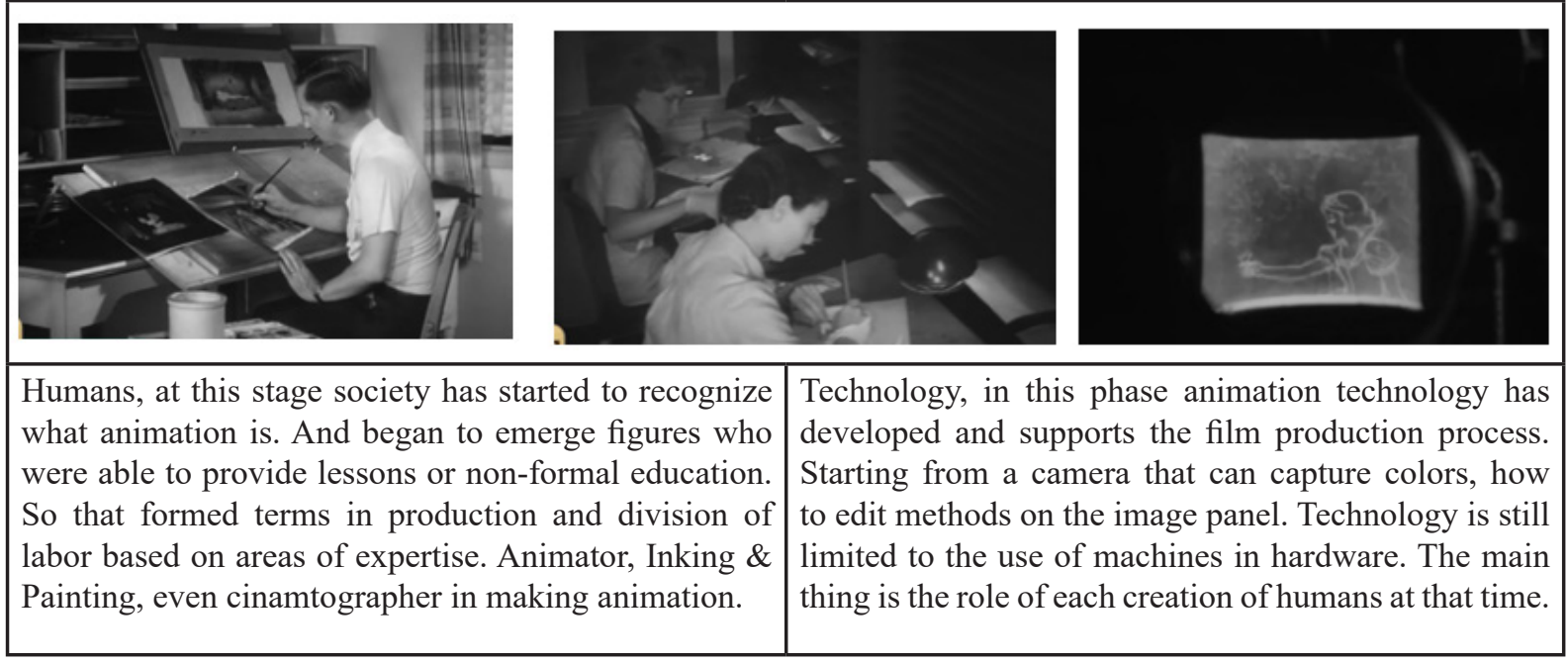

The Television Age (1958-1985), this television era animation began around 1958 when the discovery of the media called television and shifting the dominance of the big screen. This new media also became a place where animated films were commercialized both nationally and internationally from the countries that produced animation at that time. Because of that, changes began to occur in producing animated feature films, into serial films. Therefore the most important thing in this century is the number of workers, the speed of production. Then in terms of technology, many new machines are also supporting in the work of animated films starting from photocopiers to make it easier to draw the basics of the movements then make details in the work of the drawing panels. A faster camera photographing panel images, like today's scanning tools but with a larger size. Celluloid film for better color.

Table 4 Fourth chapter - The Television Age

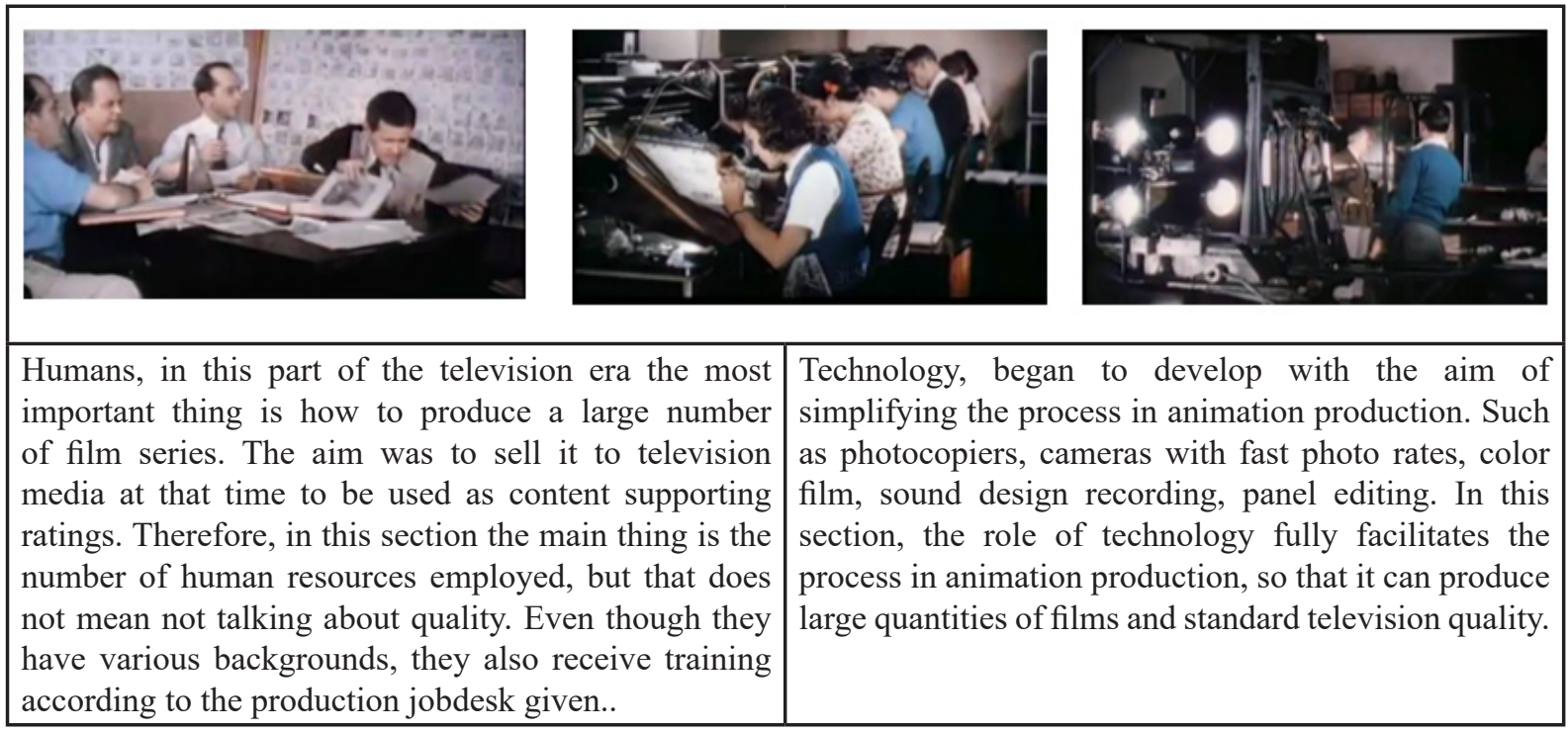

The Digital Dawn (1986 - Now). This fifth chapter is the last chapter that exists to this day, where there is a big digital technology discovery and affects the development of animation in its production process. Changes in the way of thinking from 2 dimensions to 3 dimensions in the animation production process. The production process, which previously relied on hardware to produce animated films, has changed to digital or software production. A big marker in this era is the big screen film Toy Story from Pixar animation Studio in 1995. The pattern of work and jobdesk changes, a simple example used to need in beetweener to draw a continuation of extreme poses in animated films (Thalmann, N. \& D, 1996).

Now the computer plays a role in making the in between. Academics began to appear that were serious about providing knowledge and science related to animation and were recognized by state educational institutions. But with the academic boom in this field, the question is whether there are enough jobs for them in this area. And whether entering academia is just fulfilling the requirements of being an educated human, or really being a 
human being who has one clear goal in this field. Meanwhile, technology is a major threat to those who are not serious in this field, because technology has narrowed the area of employment. For example, in the past 1 minute animation took several people to work on, but now maybe only 1 person is enough. What is terrible is that when a lot of hardware and software (motion capture) can capture motion directly for body mechanic animation and facial animation, it can reduce the portion of work for animators later (Sharma, et al, 2013).

Table 5 Fifth chapter - The Digital Dawn
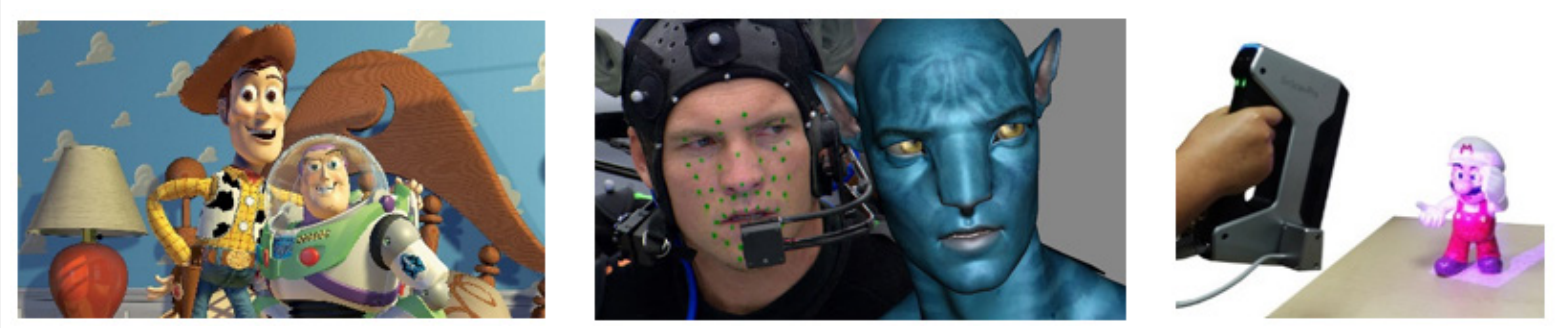

Humans, in this case there are many big changes in which humans are completely facilitated by technology. Especially when the advent of computers, which changed the systems in animation production to a large extent. What used to require a lot of human resources when working on animated films, is now made easier.

Technology, at this stage is very advanced. In fact, it is one that greatly facilitates animation work in the industry. But with all its sophistication, it can also take a role in animation production so that those who used to do animation production needed a lot of people to do it. Now it is made easier because of technology.

From all the reflections above, We can see that the development of animation in the future will completely change, not only relying on techniques within the boundaries of the aesthetic of art, but also focusing on simulation results and understanding physics (Gregor, et al, 2020). The need for an educational role that continues to be developed in the field of animation. So that education can become a resistance so that it can compete in line with increasingly advanced technological developments. Education is one of the resilience to face the flow of globalization and the labor market in the future, especially after many production systems have been simplified due to technology assistance (Sugiharto, 2013). The answer to how humans can coordinate with technology in the future is innovation in the learning process that enhances new human skills to master technology.

\section{CONCLUSION}

This research is limited to a historical study of the development world animation through a comparison between humans and the technology. It can be concluded that in the 21 st century, is an era technology is developing rapidly. This will change the application and method of creating animated films. Especially there is a challenge that the role of humans in the animation industry is diminishing. The superior human philosophy is the human with paidea - arête, namely education. Education will make humans not only have intelligence, but is able to have the ability to master the technology and use it in future animation. For further research, researchers can develop an innovation structure on animation education on the basis of the application of human resources and technology. 


\section{REFERENCES}

Cavalier, S. (2011). The world history of animation. London: Aurum.

Gregor, M., Horejsi, P., \& Šimon, M. (2020). Case Study: Motion Capture for Ergonomics. Innovation Vision 2020: From Regional Development Sustainability to Global Economic Growth, 468-476.

Harari, Y. N. (2014). Sapiens: A Brief History of Humankind by Yuval Noah Harari. The Guardian.

Harari, Y. N. (2017). Homo Deus. In Homo Deus. https://doi.org/10.17104/9783406704024

Harari, Y. N. (2018). Tantangan Teknologi. In 21 Adab untuk abad ke 21 (1st ed.). Manado: CV.Global Indo Kreatif.

Kurnianto, A. (2015). Tinjauan Singkat Perkembangan Animasi Indonesia dalam Konteks Animasi Dunia. Humaniora, 6(2), 240. doi:10.21512/humaniora.v6i2.3335

Samho, B. (2008). Humanisme Yunani Klasik dan Abad Pertengahan. In B. Sugiharto (Ed.), humanisme dan humaniora. Bandung: Pustaka Matahari.

Sugiharto, B. (2013). Humanisme dan Pendidikan Bagi Masa Depan. In B. Sugiharto (Ed.), humanisme dan humaniora (II). Bandung: Pustaka Matahari.

Sharma, A., M., Sharma, A., \& P. (2013). MOTION CAPTURE PROCESS, TECHNIQUES AND APPLICATIONS. International Journal on Recent and Innovation Trends in Computing and Communication, 1(4), 251-257.

Thalmann, N., \& Thalmann, D. (1996). Computer animation in future technologies. 